JOURNAL OF ENGLISH STUDIES, II (2000), 19-34

\title{
THE SEMANTICS OF SOLIDARITY AND BROTHERHOOD IN CHINUA ACHEBE'S NO LONGER AT EASE
}

\author{
Mercedes BengoecheA \\ (Universidad de Alcalá) \\ Gema S. Castillo García \\ (Universidad de Alcalá)
}

\begin{abstract}
We intent to shed new light on the role of Pidgin, one of the languages used by Achebe's characters in No Longer at Ease. We suggest that, contrary to what some literary critics have interpreted, Pidgin, far from being the language of triviality or of the uneducated alone, represents in Achebe's work an honourable rite of passage from rural life into urban development in a multilingual post-colonial nation, and a bridge between conflicting worlds, Africa and Europe, tradition and innovation. Furthermore, a close consideration of the semantics of solidarity in the novel reveals the importance of the roles played by two languages, Ibo, and, more outstandingly, Pidgin, as vehicles of fellowship and brotherhood. This is revealed by examining the use of three of the linguistic varieties present in No Longer at Ease: Ibo, conversational English, and Pidgin. Our analysis discloses a transfer of legitimacy from English to a communally owned Pidgin.
\end{abstract}

Nigeria has some 90 million people who speak about 450 different linguistic varieties, the main ones Hausa, Yoruba and Ibo, the three of which serve over 75 million of the population and are are being developed as official languages for the north, west and east areas of the country respectively. English, introduced by the colonial administrators and early missionaries, is the official language of the country, almost exclusively a second language, spoken with varying degrees of competence all throughout the land, and used as a medium of instruction at the secondary and tertiary levels, and as the language of the administration, of the Government and of the elite. But 
the most idiosyncratic constituent of the repertoire of West Africans is Pidgin, one of the outcomes of linguistic contact in a polyglot society: it arises whenever people speaking mutually unintelligible languages need to communicate. Pidgin English has been used in Nigeria ever since the first Europeans arrived. It has been employed all along the country as a diglossically Low language of informal oral communication, both an inter-ethnic lingua franca and a relaxed or joking language (Brann 1988: 1421), for long, but nowadays, in the second half of the 20th Century, new forms of Pidgin English are emerging in many urban centres which may serve all communicative purposes (Shnukal and Marchese 1983). The complex and flexible linguistic usages of the varieties available to their speakers reflect Nigeria's constant state of flux and "expanding consciousness" (Bisong 1995: 125), and are described at their best in the works by Chinua Achebe.

From the beginning of his career, Chinua Achebe's skill for combining the role of novelist and anthropologist has been emphasized (Carroll 1980; Wilson 1979). This becomes evident in his second novel, No Longer at Ease, published in 1960, which depicts the downfall of Obi, a young "been-to"1 Nigerian who returns home after a period of study in England, becomes a civil servant, experiences an acute shortage of money, gets into debt, accepts bribes and finally is convicted of corruption. The action takes place in the 1950's, a few years before Nigerian independence, and although the novel cannot strictly be considered a historical document, it is nevertheless an ethnographic record of an African society shaking in a period of emotional upheaval and social transformation from traditional rural to modern urban life, and from colonial to postcolonial.

One of the means Achebe brings into play in order to transmit and interpret African social history is his masterly articulation of values, social identities and language. As has been noted, in the novel not only is the division between the city and the village marked by language, but "languages are closely related to values; English and Ibo $^{2}$ are not merely different ways of saying the same thing, but vehicles for expressing completely different attitudes to life. Where one language or the other proves inadequate, so for the same reasons do the values it represents" (Riddy 1979: 150). In this sense, we can claim that the role of the three languages featured in No Longer at Ease goes much further than being mere vehicles for communication. They are one of the "themes" of the novel, entities loaded with a highly symbolic value, sometimes even of more significance than the characters themselves. The linguistic variety that any given character opts for in different situations (namely standard English, Ibo or Pidgin), as well as being indexical of their social identity, testifies the changes in social relations and alliances that were

1. A local word to refer to those lucky ones who have "been to" Europe.

2. As noted above, Ibo, or Igbo, is the language of the Ibo, one of the indigenous peoples of Eastern Nigeria. 
taking place in Nigeria. Fictional conversations in Achebe's novel are thus useful tools to define the new order which was about to evolve, and to re-create the cultural transformations which were to transpire. They confirm Achebe's concern for certifying the historical changes which had occurred in Nigeria, an interest which establishes him as one of the most celebrated figures of post-colonial literature, as from the 80's postcolonial studies have highlighted the role of post-colonial writers as witnesses and anthropologists of social life.

Achebe, who sees himself as a social historian, commentator and interpreter, has claimed that African writers in the twentieth century need to write stories which follow

human societies as they recreate themselves through vicissitudes of their history, validating their social organizations, their political systems, their moral attitudes and religious beliefs... but they also serve to sanction change when it can no longer be denied. At such critical moments.. stories ... tend to be brought into being to mediate the changes and sometimes to consecrate opportunistic defections into more honourable rites of passage. (Achebe 1988: 112) (our emphasis)

In this paper we intent to shed new light on the role of Pidgin, one of the three languages used by Achebe's characters in No Longer at Ease, the first of his works where Pidgin plays a central symbolic role. We suggest that, contrary to what some literary critics and sociolinguists have interpreted, the use of Pidgin, far from being only the language of triviality or of the uneducated (Yankson 1990; Riddy 1979: 157; Zabus 1991: 82), is in this novel, and borrowing Achebe's words in the previous passage, an honourable rite of passage from rural life into urban development in a multilingual postcolonial nation, and a bridge between conflicting worlds, Africa and Europe on the one hand, tradition and innovation on the other. Pidgin does not represent in Achebe an abandonment of pure African modes or a dereliction of the duty of maintaining Ibo spiritual idiosyncrasy, that is, it is not an opportunistic defection. Instead, one of the most important of Achebe's achievements has been to sanction linguistic and cultural change and to consecrate a mixed hybrid impure denigrated code which enacts the difficult process of compromise: Pidgin.

Furthermore, our hypothesis is that a close consideration of the semantics of solidarity in the novel may reveal the importance of the roles played by two languages, Ibo and (perhaps more outstandingly) Pidgin, as vehicles of solidarity and brotherhood. This we shall reveal by examining the use (either in dialogues or in authorial comments) by the fictional characters of No Longer at Ease of three linguistic varieties: Ibo, conversational standard English, and Pidgin ${ }^{3}$.

3. The fourth variety would be literary English (Riddy 1979: 155). 
In order to analyse the semantics of the three languages, and starting from the premise of the multifunctional treatment of Pidgin in the novel, we shall not be concerned with how the language helps to shape style, characters or situations, but rather, we shall be focusing on instances in which Pidgin and the other two linguistic varieties become powerful instruments to convey cultural meanings of affiliation or disaffiliation. In the pages which follow, then, and with an aim to establish the overall significance of each of the three linguistic codes throughout the novel, we shall not be particularly interested in the communicative role of the languages, but in their identificative or disidentificative role only. We shall concentrate particularly in situations where characters use one of the languages or another to establish their identity and alliance to a social group, and shall consider code-switching ${ }^{4}$ between the three languages as acts of identity of multi-faceted fictional characters.

\section{Iво (OR IGBo)}

Following a tacitly established convention in West African novels, Ibo, the mother tongue of Obi, Clare and most of the protagonists, is typically rendered in the novel by a cadenced, rhetorical, proverb-laden standard English. Rich in images, tales, songs and phrases drawn from traditional African rural life, with maxims, sententiousness, and proverbs (Riddy 1979; Jones 1964, 1965), Ibo is the language of Umofian identity and cultural filiation, encoding traditional Umofian values ${ }^{5}$. All through the novel, whenever Achebe renders Ibo style into English in the mouth of one of the characters, the mode of speech stands for a traditional view and perspective, as in Joseph's comment, when he reacts using Ibo after Obi has accused him of having a "colonial mentality" because he endorses and defends traditional roles: «'Call it what you like', said Joseph in Ibo. 'You know more book than I, but I am older and wiser. And I can tell you that a man does not challenge his chi to a wrestling match'» (37). As Riddy puts it: "the 'Ibo' style not only stands for a mode of speech but also symbolizes a whole way of life: ceremonial, ordered, governed by traditional wisdom and rooted in the soil" (1979: 152). That is why when Christopher, Obi's friend, in order to find words of advice and encouragement, after a sentence in English, resorts to Ibo, bringing up the story of the bedbug, a tale which belongs to Umofian traditional heritage and knowledge:

4. Code-switching refers to the use of two or more linguistic varieties in the same conversation. It is quiete common in societies where people are polyglot, and has been studied as a strategy of projecting two or more social and political identities at the same time or alternatively.

5. Umofia is an Ibo town in Eastern Nigeria, the home town of Obi, the main character of the novel. 
«Obi had been advised not to try to see Clara again in her present frame of mind. 'She will come round,' said Christopher. 'Give her time.' Then he quoted in Ibo the words of encouragement that the bedbug was said to have spoken to her children when hot water was poured on them all. She told them not to lose heart because whatever was hot must in the end turn cold. » (144)

Apart from that, Ibo also represents the language of the clan and a sense of ethnic brotherliness. This is reflected in the fact that Obi uses standard English at the office, but turns to Ibo when he speaks to some of his people and does not want Miss Tomlison, the British woman who shares his office, to understand: «He sent for Charles and asked him in Ibo (so that Miss Tomlinson would not understand) why he had not fulfilled his promise» (88). Although this switch into Ibo might be interpreted only as a wish to ensure secrecy in conducting their talk, it also helps to reinforce brotherhood ties, as Charles is thus reminded firstly that he is part of the in-group of speakers of Ibo, and then that he should have fulfilled his promise of paying back the money he had borrowed from Obi.

Obi also switches to Ibo when requested by Mr. Mark, a fellow countryman who is trying to bribe him: «If you don't mind, shall we talk in Ibo? I didn't know you had a European here» (78). Mr. Mark's comment is suggesting Obi's "obligation" towards him who belongs to the group of his kinsmen. Ibo is here a symbolic means to bring to Obi's mind the established fact that for any Umofian their primary duties are to the clan, and, ostensibly, using his influence should be one of them.

Convergence towards Ibo seems to be the essential requirement for the recognition of ethnic fellowship, as Miss Mark exemplifies in her intentional switch into the local variety when she visits Obi to offer herself as the "price" for bribery: "'You must be surprised at my visit'. She was now speaking in Ibo» (82). And conversely, the use of Ibo entails the acknowledgment of mutual ethnic alliance, as when the policeman at the Victoria Beach Road changes his hostile attitude and converges his speech when he discovers that Obi and Clara are, like himself, Ibo: «Clara told me in Ibo to call the driver and go away. The policeman immediately changed. He was an Ibo, you see. He said he didn't know we were Ibos» (67).

As a result, when interacting with a fellow countryman, divergence from Ibo into English means lack of membership, as when Obi is tempted to bribery for the first time. In spite of Mr. Mark's efforts to convince Obi to help him -by means of using Ibo and even appealing to Ibo values: «I was told that you are the secretary of the Scholarship Commission, and I thought that I should see you. We are both Ibos and I cannot hide anything from you» (79)-, Obi rejects the idea of taking bribes from him in exchange of getting a scholarship for his sister. This rejection is shown in his comments and in his detachment through his use of English: «I'm sorry, Mr. Mark, but I really don't 
understand what you are driving at.' He said this in English, much to Mr. Mark's consternation» (79).

The same lack of acknowledgement of membership by not reciprocating in the use of the shared mother tongue can also be seen in the early stages of Obi and Clara's affair. He and Clare, the girl he falls in love with, belong to the same people, both are Umofian and share the same native language. They meet at the ship when both come back from Britain, and interact in English at the beginning. After a couple of days, Obi got seasick, and then she gave him some tablets, while addressing him in Ibo: «She had treated him just like another patient... but then she had spoken in Ibo for the first time, as if to say, 'We belong together. We speak the same language'» (22). Her using Ibo creates a feeling of comradership in Obi which he attempts to maintain next morning. However, as if afraid of any kind of personal attachment to him, Clare intentionally diverges into English and the conversation continues in this language: «'Thank you for the tablets', he said in Ibo; 'Did they make you feel better?', she asked in English» (22).

Although Ibo gave Obi pleasure in London, as the reader infers from the episode in which we are told that: «he spoke Ibo whenever he had the least opportunity of doing so. Nothing gave him greater pleasure than to find another Ibo-speaking student in a London bus» (45), things change when he he is back in Nigeria. Back home he begins to feel oppressed by the burden of the impositions of his people, who had paid eight hundred pounds to train him in England, and expected that the communal effort in sending him to England, an investment which must yield heavy dividends (on influence), should revert to the clan. As Carroll suggests: "As soon as Obi gets home, the claims of kinship begin to reassert themselves almost imperceptibly through the casual introduction of songs, tales and proverbs. These, which were part of the accepted texture of traditional life in Umofia, now nag persistently at the independence of the hero" (1990: 79). Trapped between his personal life and the communal demands, he will challenge the latter and will disappoint the clan first by not using his profession to pay back his fellow villagers, and then by trying to marry an $o s u$ girl, an outcast. And just as Obi feels himself liberated from the rigid conventions and obligations of his clan, he loses mastery of the Ibo language. Obi is not even able to find an appropriate Ibo proverb when he looks for it, and Clara recriminates him: «I have always said you should go and study Ibo» (99). In addition, he gets stuck and stammers at the prayers in his father's house, and when he tries to speak Ibo at the meeting of the Umuofia Progressive Union, he fails. His informality is misinterpreted as heedlessness. As his friend Joseph put it, «Obi's mission-house upbringing and European education had made him a stranger in his own country» (64-5).

Obi's reluctance to compromise and his inability to understand and keep to the values of the language in the Nigerian linguistic community is a crucial ingredient in his 
fall. His is a community characterized by a respect for the spoken word, where the language of formal rhetoric, sermons and ceremonial address is deeply appreciated, as Obi himself puts it: «Let [the British] come to Umofia now and listen to the talk of men who made a great art of conversation» (45). Obi's combination of social circumstances and personal qualities (an intelligent educated "been-to", with theoretically a perfect command of Ibo, and whose expensive education had been funded by the Ibo village of Umofia) should have produced an accomplished talker drawing on themes, conventions and material handed down from previous generations. Instead, he will diverge from the expectations of the clan and will renounce this heritage, adopting the neo-western value of casualness and informality, which will make him grow further apart from his ethnic group. The loss of control over his native language is a fundamental step in his process of disidentification with Umofia and its customs. His incompetence in the vernacular helps him to dissociate himself from the rural traditional background which he deems too heavy a burden and a nuisance in the modern metropolis. The Ibo language is a reminder of his clan and duties which he must forget in order to accommodate to urban integration and successful detribalization. Significantly Obi, the name of the protagonist, is spelled in reverse order to Ibo, as if he represented a turn round of Ibo's standards and principles.

Obi's failure in the novel then is perhaps not grounded, as Riddy puts it, in his inability "to find a means of expression" (159), but in his inability to find a symbolic vehicle for brotherhood once he has accepted that the traditional modes and views that Ibo represents are not valid for him any more. Instead of acknowledging his filiation to the African indigenous tongue, which he has somehow abandoned, he mistakenly turns to English.

\section{ORDINARY CONVERSATIONAL ENGLISH}

When Obi was in England with other Nigerians from different ethnic groups who did not share Obi's mother tongue, English represented for him the "default" code (Bokamba 1991: 499). He felt ashamed about this language though, as stated here:

When he had to speak in English with a Nigerian student from another tribe he lowered his voice. It was humiliating to have to speak to one's countryman in a foreign language, especially in the presence of the owners of that language. They would naturally assume that one had no language of one's own. (45)

Although in England there was no other alternative language -thus the language of "lack"-, when he arrives in Lagos, English becomes the language he chooses for most of 
his interactions. As a "been-to", he now feels part of the sophisticated avant-garde who defiantly challenges some African customs, -the ban to marry an osu among them-, and resists tribal impositions, not yielding even to the tradition of using formal oral Ibo and formal clothes for ceremonies, as stated above. Detached from Ibo and its values, Standard English represents allegiance to a particular post-colonial system of signification: that of the educated élite.

Back home, English has transformed itself in a badge of prestige and a mark of Westernization. As a "been-to", Obi feels proud of his English: after all, it was the subject he studied for his degree. His adherence to English represents for him membership in "the shining élite" (90) which was beginning to consolidate itself as a class and which will recognize themselves as a group through an adopted code, that of standard English, the language of identification with la crème de la crème, the members "of an exclusive club" (90). Standard English, with its authoritative connotations as dominant language, is therefore both a means to impress and the language of position, as can be seen in Joseph's use of English on the phone, which reveals his desire to sound important in front of his audience, to become a member of that "shining élite": « Good! See you later'. Joseph always put an impressive manner when speaking on the telephone. He never spoke Ibo or pidgin English at such moments» (70). As regards Christopher, another of Obi's friends, we perceive how he uses Standard English to show that he knows "how to move in élitist circles" (Schmied 1991: 130).

In the novel, standard English in conversation clearly stands for lack of solidarity with the powerless, as we have seen in Obi's attitude towards Mr. Mark mentioned above. This is also clearly revealed in several instances of interaction between Obi and lower-status characters. In those examples, Obi diverges consciously into English as a sign of indignation or disagreement, which may be interpreted as a bid for authority. His attemp to redefine the interaction in the power arena is patent when he is talking to Charles, one of the department's messengers, or in some occasions that he is speaking to his servant Sebastian. For instance, when he had decided to introduce "sweeping economy measures in his flat" (89), he tells so to Sebastian in English. The servant answers back in Pigdin, to which Obi converges using Pidgin as well. But then, as if afraid that Pidgin might undermine his authority, and as a way to re-establish his power, he turns to standard English again:

«The fridge must be switched off at seven o'clock in the evenin and on again at twelve noon. Do you understand?'

'Yes, sir. But meat no go spoil so?'

'No need to buy plenty meat at once.'

'Yes, sir' 
'Buy small today; when he finish buy small again.'

'Yes, sir. Only I tink you say I go de go market once every week'.

'I said nothing of the sort. I said I would only give you money once.'» (92)

Obi diverges from Ibo or Pidgin into English when he wants to show lack of solidarity, distrust, or disagreement, adopting the language of power towards the less or non-educated, as in this other instance with his servant Sebastian:

«When he got back to the flat he told Sebastian not to cook any supper.

I don start already. ${ }^{\prime 6}$

'Then you can stop,' he shouted.» (93)

Standard English may also be used to express the power exerted by (educated) male speakers towards women, this being exemplified in Christopher's use of this linguistic variety when interacting with one of his girlfriends, Bisi. Christopher, who had been speaking Pidgin to show that he was not rich enough to offer his visitors champagne to drink, turns into standard English when he listens to his girlfriend say in Pidgin that she would like to go to the cinema:

«'What are you people doing this evening? Make we go dance somewhere?'

Obi tried to make excuses, but Clare cut him short. They would go, she said.

'Na film I wan' go, 'said Bisi.

'Look here, Bisi, we are not interested in what you want to do. It's for Obi and me to decide. This na Africa, you know’» (100).

Standard English becomes here the tool for downgrading Bisi's opinions, bestowing importance on men.

Significantly, ordinary conversational English in No Longer at Ease has no distinctive rhetoric; it is laconic, almost abrupt (Riddy 1979: 155-6) and coincident with the casualness of relationships in colonial urban society, which lack a genuine sense of community. It is especially represented in the language spoken at the club in Lagos. When Obi endeavours to speak it, "he is in a sense acting out a part" (Riddy 1979: 156), as if wearing a mask which permits playing a role, but which in the end proves to be not a tool for communication but a master over speakers.

In spite of the fact that standard English makes Africans "European", the ambivalence of their position is reflected in the fact that occasionally, when they wish to dissociate themselves from expatriate attitudes or feel uncertain about their own

\footnotetext{
6. 'I have already started '.
} 
position, they switch into Pidgin. As an example of dissociation with the language of the colonizer, we can refer to the episode of Obi's deliberate mispronunciation of an English sentence when he wants to show his disapproval for not being served Nigerian food at the "Palm Grove", the restaurant in Lagos: «Then he added in English for the benefit of the European group that sat at the next table: 'I am sick of boilèd potatoes.' By calling them boilèd he hoped he had put into it the disgust he felt.» (31).

Even more revealing of the cultural meanings of standard English are those instances in which Obi chooses to switch from English into Pidgin as a way to show his affiliation with Nigerian urban folks, as when he was interacting on the phone with the receptionist downstairs: «A gentleman? Send him up, please. He want speak to me there? All right, I de come down. Now now'» (78). Solidarity towards urban speakers is also expressed in Obi's interactions in Pidgin when addressing the school boys in the Imperial's parking («Na me go look your car for you [...] O.K. make you look am well» (101), or when speaking with Samsom, Hon. Sam Okoli's steward: «Wetin Master and Madam go drink? [...] Make you no worry, Samson» (86).

Those dialogues manifest that Pidgin had already become the new symbolic element of a new alliance: that among post-colonial individuals in a multicultural and polyglot setting, in which, as Zabus has remarked, there may be a "need to do away with the formality and unnaturalness of Standard English in the social arena" (1991: 84), and with its connotations of power and distance.

\section{PIDGIN}

The main character of the novel, Obi, stands for the hybrid mixture of several cultures and forces: European education, Christian religious thought filtered by the African mind, traditional tribal Africa, colonialism, and attraction for the city (one of the outcomes of twentieth-century development), not fused and consolidated yet, but in a process of change which in that historical moment results in a conflicting salmagundi, a miscellaneous potpourri. Although it has been pointed out that those various ingredients of Obi's background "remain quite separate and unsynthesised" (Carroll 1990: 83), this being a fact which will partly account for his failure, a careful reading of the novel reveals that even though the main characters may still be on the verge of crystallising (but have not crystallised yet) out of these disparate fragments, there is a symbolic element all through the novel which represents the fusion and welding which has already emerged out of that miscellany of cultural elements: Pidgin, the linguistic outcome of the melting of several cultural and linguistic traits in the pot of the towns of West Africa. 
Pidgin is the language which belongs par excellence to urban Nigeria: a compromise between Europe and Africa, the skill manipulation of the two worlds, one of the ways to redress the balance and reconcile conflicting cultures and modes of thought. Pidgin is a language built to suit new African conditions. As Gerard claims, "Culture change always involves language change and ... culture contact, even in the form of notorious culture clash, always leads to the mode of linguistic hybridization" (1991: ii). Far from being the language of a semi-literate urban sub-culture as depicted in novels such as Cyprian Ekwensi's Jagua Nana (1961), or Joseph Mangut's Have Mercy (1982), and in plays such as those by Soyinka, or Ola Rotimi's Our Husband Has Gone Mad Again (1977), Achebe chooses Pidgin as a side-effect of the "civilising" process of colonization on African cultures, one of the ways for Africans to superpose two apparently irreconciliable sets of cultural elements.

Apart from its obvious function of lingua franca of the non-educated in multilingual Nigeria $^{7}$, Achebe starts using pidgin in No Longer at Ease as the informal and more personal language of urban characters living in West African towns, spaces where influences and cultures meet, and tribal identities blur. It is the tongue fashioned in the African city, a place which "stands midway between Europe and Umofia, and creates its own highly spiced amalgamation of their cultural ingredients" (Carroll 1990: 65). This can be seen in urban characters such as Mr. Omo, the Nigerian Administrative Assistant at Mr.Green's service, who expresses himself in Pidgin in several instances, or the African steward at the Palm Grove Restaurant, the witty nurse at the doctor's surgery, or the two ward servants at the hospital, among others. Most of those characters speak Pidgin, not in default of English, but side by side with it. Pidgin is thus "elevated to the status of a legitimate register, worthy of rivalling Standard English" (Zabus 1991: 78) in conversation.

Pidgin also serves in Achebe the purpose of expressing urban-folk philosophy, in social remarks such as the ones made by the patients waiting at the doctor's surgery when Obi jumps the queue: «you tink because Government give you car you fit do what you like? You see all of we de wait here and you just go in. You tink na play we come play» (137); or in the scene where the taxi driver runs over a dog and explains Obi: «Na good luck [...] Dog bring good luck for new car. But duck be different. If you kill duck you go get accident or kill man» (14). Its function is probably one means of insisting on African otherness, and to remind the reader that Africans possess a system of thought and a culture of their own. In fact, as Zabus notes, Pidgin has "developed an as yet tiny arsenal of maxims and urban saws which complement the original proverbs or stand on

7. As used by the coach driver and his passengers in chapter 5 , and by the people he meets in chapter 15 , when he is driving back to Lagos after visiting his parents. 
their own" (1991: 75). In No Longer at Ease, Achebe occasionally resorts to one of those to illustrate the narrator's words, as in:

«Ibo people in their fair-mindedness, have devised a proverb which says that it is not right to ask a man with elephantiasis of the scrotum to take on smallpox as well, when thousands of other people have not had even their share of small diseases. No doubt it is not right. But it happens. "Na so dis world be", they say». (90)

Even more importantly, the brotherhood of the dispossessed is also expressed through Pidgin, which is also a medium to create solidarity with fellow urban people, as opposed to Ibo, which fulfils the function of creating solidarity with fellow countrymen, and as opposed to English, the imperial dominant language. Thus, after using English on the phone, Joseph switches to Pidgin to talk to his colleagues: «That na my brother [...] 'E no be like dat. Him na gentlemen. No fit take bribe» (70) as a sign of his solidarity attitude, which shows his personal and informal relationship with his mates at work. This connotation of informality and camaraderie that Pidgin holds has been noted by some critics, who suggest that Hon. Sam Okoli's speech, whenever he feels at ease and expansive among a few friends, "slips" [sic] into Pidgin (Ravenscroft 1969:18; Wilson 1979: 166).

When the speakers want to diverge from the conversation held in Pidgin, they turn into the language of power, English, which acquires a non-solidarious, impositive connotation. We have already mentioned Obi's indignation with Sebastian and his disagreement with Charles, the messenger, and in both cases Pidgin disappears and the speaker reverts into English. A more significant example of this non-supportive attitude is found in Obi's episode with the Customs Clerk, who tries to bribe him. The interaction starts in English, but the Clerk continues his speech in Pidgin when he feels uncomfortable using the standard language. It seems that bribery is better dealt with in Pidgin, this suggesting a sense of urban brotherhood in crime which Obi rejects:

«I can be able to reduce it to two pounds for you.'

'How?' asked Obi?.

'I fit do it, but you no go get Government receipt.'

For a few seconds Obi was speechless. Then he merely said: ‘Don’t be silly. If there was a policeman here I would hand you over to him.'` (27)

Something similar occurs when Obi was paying a short visit to Umofia, his home town. While he was travelling on a coach (a mammy-wagon, as they say), its driver tried to bribe two policemen. Considering that he is above that kind of things, Obi consciously refuses to converge towards the language of solidarity: 
'Why you look the man for face when we want give um him two shillings?,'8 [the driver] asked Obi.

'Because he has no right to take two shillings from you,' Obi answered.

'Na him make I no de want carry you buk people, ${ }^{\text {'9 }}$ he complained. (39)

\section{CONCLUSION}

For some time, African critics interpreted the use of Pidgin in novels by white writers as a subjective characterization of African speakers as linguistically incompetent and even inferior. Chantal Zabus explains this stigmatization of Pidgin in literature written by white authors when she discusses the pidginization of Joyce Cary's novel Mister Johnson: "[Joyce Cary's] rendering of Pidgin has been seen as part and parcel of a colonialist strategy aimed at establishing a captious equation between the 'baby talk' of [the Nigerian character] Mister Johnson and his putatively infantile mind" (Zabus 1991: 59).

Following this line of thought, some eminent (African and European) scholars have done what we consider neo-colonial readings of the function of Pidgin in West-African anglophone literature. Uncritically accepting common widespread (colonial) attitudes towards the languages, they have come to consider Pidgin in literature as the language of triviality alone ${ }^{10}$. Surprisingly, not even Nigerian sociolinguists escape from this perspective: Yankson, for example, interprets the narrator's comments on Pidgin all through No Longer at Ease as "clearly showing how low or unsophisticated pidgin is regarded" (1990: 5). He considers that the characters "do not use Pidgin for any serious purpose" (1990: 6), and that "its use is confined to topics which are not serious. This [...] shows that the author, consciously or unconsciously, wants us to feel that in the world of No Longer at Ease pidgin is a sub-standard language" (1990: 7). Even Chantal Zabus' analysis, although much more multifold, remarks that codeswitch from Pidgin to English in No Longer at Ease "may signal that the locutor relinquishes 'the levity of Pidgin' to broach a serious topic" (1991: 82). In most West African novels, she adds, "Pidgin remains an 'auxiliary' language into which a character slides, slips, lapses, as in a fall

8. 'Why did you look into his face when I was giving him two shillings?'

9. 'That's why I don't want to carry educated people on my coach'

10. Mocking those Africans conscious of their social or educational status who despise Pidgin, Achebe himself will ironically refer to this by putting the following words in one of his characters' mouth in a later novel «'But Standard Six in your time was superior to Senior Cambridge today', I said in our language, refusing to be drawn into the levity of pidgin» (Achebe 1966: 99, our emphasis). 
from a higher register" (1991: 76, our emphasis), something which had also been stated by other critics before, as we mentioned (Ravenscroft 1969:18; Wilson 1979: 166).

These interpretations, in our view, not only help to perpetuate the colonial status of Pidgin as a mere contact language, therefore contributing to the linguistic imperialism (or colonial "glottophagia", as Louis-Jean Calvet called it), but they are inaccurate as well, as they fail to see the crucial role played by Pidgin in No Longer at Ease.

What Achebe does is to acknowledge Pidgin as one of the several components of the linguistic repertoire of the immigrant population of Nigerian urban centres, and as a lingua franca of inter-class and inter-ethnic interaction, characterized by a multiplicity and specificity of functions as represented in Achebe's novel. Although Griffiths, discussing later novels by Achebe, has suggested that some characters use Pidgin as a (negative) "mark of 'successful' detribalisation and social advancement" (1979: 79), and Chantal Zabus remarks that in Cyprian Ekwensi's novels "Lagos emerges as a linguistic crucible seething with Pidgin-speaking characters. Pidgin [...] here becomes the lingua franca of materialistic and ambitious characters caught in the whirlpool of modernity" (1991: 65), we observe that in No Longer at Ease this is not the case yet (if it ever will be).

In Achebe's novel, Pidgin is patently the link between two worlds. Faced with the dilemmas and conflicts of the complex African society of the 50's and 60's, the only possible accommodation is Pidgin. It represents a certain African encoding of reality, the reality of a people who have come to terms with their history, culture and influences in ways that permit them to survive. It is a way to "answer back" white society as well, and thus not the lingua franca of the uneducated but a new code which in this novel is at the same time the tongue of urban people and the language of modernity, "the language of urban integration", which "reflects both her successful integration in the urban milieu and her alienation from her original linguistic community", as Zabus put it to refer to one of the female characters of Ekwesi's novels (1991: 68). Pidgin represents symbolically the urban aplomb to manipulate several cultures, and Achebe depicts characters who successfully manipulate and reconcile the different worlds, as for example, the Hon. Sam Okoli: «'Lady first; that is what the white man has brought. I respect the white man' [...] 'All the same they must go. This no be them country'» (61-2).

Achebe's utilization of Pidgin is a way to demonstrate how Africans have "indigenized" English, subverting the dominance of the standard, and investing Pidgin with a new legitimacy and authority. He has inherited a rich African culture which regards highly the values of solidarity and community. As Skinner puts it, "If the European literary archetype for two hundred years has evolved round the rebellious gesture, then its modern African counterpart is the communal act" (1998: 82). The new communality and the compromise between Western and native impulses is expressed in Achebe's No Longer at Ease by his characters' use of Pidgin. By doing this, one of his 
foremost achievements is an undermining of linguistic hierarchies, dislocating European canonical views on language, and displacing conversational English, the Nigerian "stepmother tongue", to the bottom of the set of values.

\section{REFERENCES}

Achebe, C. 1960. No Longer at Ease. London: Heinemann.

Achebe, C. 1966. A Man of the People. London: Heinemann.

Achebe, C. 1988. "What has literature got to do with it? (Achebe's Nigerian National Merit Award Lecture of August 1986)". Hopes and Impediments: Selected Essays 1965-1987. London: Heinemann.

Bisong, J. 1995. “Language choice and cultural imperialism”. ELT Journal 49 (2): 122-32.

Bokamba, E. G. 1991. "West Africa" in English Around the World: Sociolinguistic Perspectives. Ed. J. Cheshire. Cambridge: Cambridge University Press. 493-507.

Brann, C.M.B. 1988. "West Africa" in Sociolinguistics Soziolinguistik. Eds. U. Ammon, N. Dittmar, and K.J. Mattheier. Berlin: Walter de Gruyter. 1414-29.

Calvet, L-J. 1974. Linguistique et colonialisme. Paris: Payot.

Cary, J. 1975 (1939). Mister Johnson. London: Longman.

Carroll, D. 1980 (1970). Chinua Achebe. London: Heinemann, 2nd revised edition.

Carroll, D. 1990 (1980). Chinua Achebe:Novelist, Poet, Critic. London: Macmillan, 2nd edition.

Ekwensi, C. 1961. Jagua Nana. London: Heinemann.

Gérard, A. S. 1991. "Preface" to Chantal Zabus, The African Palimpsest: Indigenization of Language in the West African Europhone Novel. Amsterdam: Rodopi.

Griffiths, G. 1979. "Language and Action in the Novels of Chinua Achebe" in Critical Perspectives on Chinua Achebe. Eds. C. Innes and B. Lindfors. London: Heinemann. 67-85.

Jones, E. 1964. "Language and Theme in Things Fall Apart". A Review of English Literature 4: 37.

Jones, E. 1965. “Achebe's Third Novel”. JCL 1:176-8.

Mangut, J. 1982. Have Mercy. London: Macmillan.

Riddy, F. 1979. "Language as a Theme in No Longer at Ease" in Critical Perspectives on Chinua Achebe. Eds. C. L. Iness and B. Lindfors. London: Heinemann. 150-59.

Ravenscroft, A. 1969. Chinua Achebe. London: Longman. 
Rotimi, O. 1977. Our Husband Has Gone Mad Again. Oxford: Oxford University Press. Schmied, J. 1991. English in Africa. London: Longman.

Shnukal, A. and Marchese, L. 1983. "Creolization of Nigerian Pidgin English: A progress report”. English World-Wide 4: 17-26.

Skinner, J. 1998. The Stepmother Tongue: An Introduction to New Anglophone Fiction. London: Macmillan.

Wilson, R. 1979. "Eliot and Achebe: An analysis of some formal and philosophical qualities of No longer at Ease" in Critical Perspectives on Chinua Achebe. Eds. C. L. Iness and B. Lindfors. London: Heinemann. 160-68.

Yankson, K. E. 1990. Chinua Achebe's Novels: A Sociolinguistic Perspective. Obosi (Nigeria): Pacific Publishers.

Zabus, C. 1991. The African Palimpsest: Indigenization of Language in the West African Europhone Novel. Amsterdam: Rodopi. 